\title{
HUBUNGAN UMUR, KEBISINGAN DAN TEMPERATUR UDARA DENGAN KELELAHAN SUBJEKTIF INDIVIDU DI PT X JAKARTA
}

\author{
Karina Wahyu Andriani \\ PT. Aerofood ACS \\ Jl. Prof. DR. Soepomo No. 45 Tebet \\ Email: karinawahyuandriani@gmail.com
}

\begin{abstract}
Fatigue is one of the causes of accidents. According Setyawati (2010) fatigue shown to contribute more than 60\% in the event of an accident. This reseacrh was conducted to determine the relationship of the individual characteristics, noise and air temperature with subjective fatigue. Fatigue can be caused by various factors of education, health, habits, motivation, temperature, radiation, and humidity to the air and noise work environment. reseacrh observational descriptive with cross sectional approach. The number of samples this study were 45 people, were taken by simple random sampling. The independent variables were age, noise and air temperature. The dependent variable of this study was fatigue. The statistical test used chi-square test. Primary data were obtained from interviews and measurements directly. Measurements were taken at two locations new office and workshop 9. The results of this study showed that 45 respondents (88.90\%) had mild fatigue, and 5 respondents (11.10\%) experienced moderate fatigue. All respondents who experienced fatigue being exposed to noise and temperature exceeding the standarize. The conclusion from this study is there is no significant relationship between noise $(p=0.31)$ and air temperature $(p=0.41)$ with subjective fatigue. While age with subjective fatigue have a significant relationship with the value $(p=0.61)$. Advice for company made policy so workers over 40 years old can be get jobs that match their abilities.
\end{abstract}

Keywords: age, noise, temperature, fatigue

\begin{abstract}
ABSTRAK
Kelelahan merupakan salah satu penyebab kecelakaan kerja. Menurut Setyawati (2010) kelelahan kerja terbukti memberikan kontribusi lebih dari 60\% dalam kejadian kecelakaan. Penelitian ini bertujuan untuk mengetahui hubungan umur, kebisingan dan temperatur udara dengan kelelahan subjektif. Kelelahan kerja dapat disebabkan berbagai faktor pendidikan, kondisi kesehatan, kebiasaan, motivasi, suhu, radiasi, serta kelembapan udara dan kebisingan lingkungan kerja. Penelitian ini bersifat observasional deskriptif, dengan pendekatan cross sectional. Jumlah sampel dari penelitian ini sebanyak 45 orang, diambil dengan cara simple random sampling. Variabel bebas penelitian ini adalah umur, kebisingan dan temperatur udara. Sedangkan variabel terikat penelitian ini adalah kelelahan Kerja. Uji statistik yang digunakan uji chi-square. Data primer yang didapatkan dari hasil wawancara dan pengukuran secara langsung. Pengukuran dilakukan di dua lokasi yaitu kantor baru dan workshop 9 . Hasil penelitian ini menunjukkan bahwa 45 responden $(88,90 \%)$ mengalami kelelahan ringan, dan 5 responden $(11,10 \%)$ mengalami kelelahan sedang. Semua responden yang mengalami kelelahan sedang terpapar kebisingan dan temperatur melebihi NAB. Kesimpulan dari penelitian ini adalah tidak ada hubungan signifikan antara kebisingan $(\mathrm{p}=0.31)$ dan temperatur $(\mathrm{p}=0.41)$ udara dengan kelelahan subjektif, Sedangkan umur dengan kelelahan subjektif memiliki hubungan yang signifikan dengan nilai $(\mathrm{p}=0,61)$. Sebaiknya perusahaan memberikan kebijakan berkaitan dengan usia sehingga pekerja yang berusia lebih dari 40 tahun dapat mendapatkan pekerjaan yang sesuai dengan kemampuannya.
\end{abstract}

Kata kunci: usia, kebisingan, temperatur, kelelahan

\section{PENDAHULUAN}

Undang-Undang No.13 Tahun 2003 Tentang Ketenagakerjaan pada pasal 86 (2) menyatakan, untuk melindungi keselamatan pekerja/buruh guna mewujudkan produktivitas kerja yang optimal diselenggarakan upaya keselamatan dan kesehatan kerja. Berdasarkan undang-undang tersebut dapat disimpulkan bahwa pekerja merupakan salah satu faktor yang penting dalam kegiatan produksi. Pekerja merupakan faktor yang memegang peranan penting dalam suatu proses produksi, oleh karena itu perlu dilakukan upaya untuk mencegah terjadi kecelakaan kerja pada pekerja. Kecelakaan kerja akan memberikan dampak buruk baik bagi perusahaan maupun pekerja itu sendiri. Perusahaan dapat mengalami kerugian akibat kehilangan pekerja dan menanggung biaya pengobatan pekerjanya. 
Banyak upaya pencegahan yang dapat dilakukan dengan memperhatikan kondisi pekerjaan dan lingkungan kerja. Dua kondisi ini dapat berpengaruh langsung terhadap pekerja. Kondisi yang dimaksud seperti tingkat pendidikan, kondisi kesehatan, kebiasaan, motivasi, suhu, radiasi, serta kelembapan udara dan kebisingan lingkungan kerja

Kelelahan kerja merupakan salah satu hal yang dapat menimbulkan kecelakaan kerja. Hal ini sesuai dengan yang dikemukakan oleh Setiawati (2010), menyumbang lebih dari $60 \%$ penyebab kejadian kecelakaan di tempat kerja oleh sebab itu butuh penyesuaian antara faktor fisik, kimia, internal eksternal dan ergonomi di tempat kerja.

Kelelahan adalah suatu mekanisme perlindungan tubuh agar tubuh terhindar dari kerusakan lebih lanjut sehingga terjadi pemulihan setelah istirahat. Istilah kelelahan menujukan kondisi yang berbedabeda dari setiap individu, tapi semuanya berawal dari penurunan efisiensi kerja, kapasitas kerja dan ketahanan tubuh.

Kelelahan kerja ditandai oleh penurunan kesiagaan dan perasaan lelah yang merupakan gejala kelelahan subjektif. Kelelahan dibedakan menjadi tiga kelompok yaitu berdasarkan proses terjadi (fatigue), Berdasarkan waktunya terjadinya (kelelahan akut, kelelahan kronis), dan berdasarkan penyebab terjadinya (kelelahan fisik (physical), kelelahan psikologis. Banyak faktor yang dapat menyebabkan terjadinya kelelahan kerja menurut Tarwaka (2011), diantaranya faktor karakteristik individu seperti usia, jenis kelamin, tingkat pendidikan, masa kerja, status perkawinan, status gizi dan sebagainya. Faktor pekerjaan, seperti pekerjaan yang monoton, lama kerja, beban kerja, sikap kerja. Faktor psikologi dan yang terakhir adalah faktor lingkungan kerja berupa iklim kerja, kebisingan, dan penerangan.

Risiko yang dapat ditimbulkan akibat kelelahan diantaranya penurunan motivasi kerja, performansi rendah, rendahnya kualitas kerja, banyak terjadi kesalahan dalam bekerja, rendahnya produktivitas kerja, menyebabkan stres kerja, penyakit akibat kerja, cedera, dan terjadi kecelakaan akibat kerja. Hal ini yang menyebabkan dibutuhkan tindakan preventif, kuratif, dan tindakan rehabilitatif dalam mengatasi risiko tersebut.

Kebisingan merupakan salah satu faktor yang dapat mempengaruhi terjadinya kelelahan kerja. Bising adalah bunyi yang tidak disukai, suara yang mengganggu. Berkurangnya pendengaran akibat bising berlangsung secara perlahan-lahan dalam jangka waktu yang lama. Kecepatan penurunan pendengaran tergantung pada tingkat kebisingan, lamanya pemaparan dan kepekaan individu. Kebisingan bisa menyebabkan gangguan langsung pada telinga (auditory effect) juga bisa mempengaruhi bukan pada indera pendengaran (non auditory effect).

PT.X adalah sebuah perusahaan yang memproduksi, tiang listrik dan tiang lampu, serta aksesoris lainnya untuk tiang, seperti kurung, bingkai dasar mendukung dan sebagainya. PT. X memiliki luas: 39,40 m3 untuk mengatasi dengan kapasitas produksi yang besar setiap bulan dan menghasilkan setiap jenis baja struktur fabrikasi, misalnya: Struktur bangunan, jembatan, tank, menara baja, dan struktur peralatan mekanik.

Pekerjaan yang dilakukan di unit produksi adalah perakitan alat-alat yang telah dipesan, biasanya bahan baku diperoleh dari perusahaan lain. Perakitan mengunakan tenaga mesin yang dibantu oleh manusia. Faktor manusia adalah faktor yang lebih dominan karena sebagian besar mesin dijalankan oleh manusia. Hal ini yang menyebabkan tenaga kerja yang bekerja pada unit produksi sangat berisiko mengalami kelelahan kerja. Berdasarkan hasil pengamatan diketahui bahwa lebih dari $70 \%$ pekerja di PT. X berada di unit produksi yang menyebabkan sebagian besar pekerja terpapar langsung dengan faktor lingkungan sehingga dapat menyebabkan kelelahan.

Proses produksi yang dilakukan di PT. X tahapan awal yaitu menggambarkan desain, terdapat proses penggambaran detail setiap desain, selanjutnya pengambilan material yang diperlukan untuk dikirim ke workshop. Proses yang dilakukan di dalam workshop ini adalah melakukan berbagai macam proses produksi seperti welding atau pengelasan yaitu proses penyatuan atau pemotongan, gerinda yaitu proses penghalusan bagian yang kurang rapi, bending atau membengkokkan besi baja, dan press. Tahapan ketiga yaitu memasuki tahapan finishing atau proses akhir meliputi pengecekan produk apakah sudah sesuai dengan quality control.

PT. X memiliki total 11 workshop yang memiliki tugas yang berbeda-beda, namun penelitian ini hanya berfokus pada proses yang ada di workshop 9. Workshop 9 adalah area cutting dan bending, sehingga banyak pekerja yang bekerja menggunakan mesin cutting dan mesin bending. Mesin inilah yang menghasilkan bunyi keras yang tidak teratur sehingga mengganggu pendengaran 
pekerja. Kebisingan ini dapat menyebabkan kondisi tidak nyaman dan mengganggu kesehatan pekerja.

Berdasarkan hasil wawancara dengan pekerja, pekerja mengalami berbagai gejala kelelahan subjektif. Sebanyak 27\% pekerja merasakan lelah seluruh badan, 34\% pekerja mengaku sering menguap dan sebanyak $30 \%$ pekerja mengaku mengalami gangguan tidak stabil saat berdiri. Gejala kelelahan fisik paling sering dirasakan adalah nyeri punggung, sedangkan gejala yang hampir tidak pernah dirasakan oleh responden adalah tremor, sesak nafas dan merasa kurang sehat badan.

Penelitian ini bertujuan mengetahui hubungan Umur, temperatur, kebisingan dengan kelelahan subjektif di unit produksi PT X Jakarta.

\section{METODE}

Berdasarkan cara pengumpulannya penelitian ini merupakan jenis penelitian observasional karena dalam penelitian ini hanya mengamati objek penelitian tanpa memberikan perlakuan. Ditinjau dari system analisisnya termasuk jenis penelitian deskriptif yaitu suatu metode penelitian yang dilakukan dengan tujuan untuk membuat gambaran tentang suatu keadaan secara objektif. Ditinjau dari segi waktu penelitian ini termasuk penelitian cross sectional karena waktu pengambilan data dilakukan sekali, yaitu pengamatan dan pengambilan data dilaksanakan pada saat yang sama.

Penelitian ini dilakukan di PT. X yang beralamat di Tambun Jakarta. Penelitian dilakukan pada bulan Februari 2015 hingga Juli 2015. Populasi dalam penelitian ini adalah tenaga kerja pada unit produksi PT. X Jakarta sebanyak 80 orang yang diambil dari 60 orang pekerja di workshop 9 dan 20 orang pekerja di kantor baru. Alasan memilih workshop 9 untuk diteliti berdasarkan penelitian data awal yang dilakukan sehingga diketahui kondisi temperatur dan kebisingan pada workshop 9 yang paling tinggi. Penelitian juga dilakukan pada kantor baru karena kantor baru ini memiliki kondisi yang paling aman dan kebisingan yang paling tidak berbahaya. Perhitungan sampel menggunakan simple random sampling. Jumlah sampel yang diambil sebanyak 45 orang, terdiri dari 11 orang dari kantor baru dan 34 orang dari workshop 9.

Variabel yang akan diteliti yaitu: (1) faktor kebisingan pada lingkungan kategori bising yaitu $>85 \mathrm{dBA}$ dengan waktu paparan 8 jam sehari (2) umur dibedakan menjadi 3 kategori yaitu (a) $\leq 30$ tahun (b) 31-40 tahun (c) $\geq 41$ tahun (3) Kelelahan subjektif dibedakan menjadi 4 kategori dengan klasifikasi (a) tidak lelah, jika $>30$ (b) kelelahan ringan jika 31-60 (c) kelelahan sedang jika 61-90 (d) kelelahan berat jika $<91$ (5) Temperatur udara dengan menggunakan 2 kategori yaitu Normal $18-30^{\circ} \mathrm{C}$ dan Tidak normal $>18^{\circ}$ atau lebih $<30$.

Data yang dikumpulkan dalam penelitian ini adalah data primer. Data primer yang yang didapatkan dari hasil wawancara dan pengukuran secara langsung. Wawancara dilakukan dengan menggunakan kuesioner untuk mengetahui karakteristik individu responden. Pengukuran kebisingan dan temperatur dilakukan secara langsung dengan alat ukur, pengukuran dilakukan di dua tempat yaitu kantor baru dan workshop 9 .

Alat-alat serta instrumen yang digunakan pada saat penelitian ini adalah: (1) kuesioner mengetahui identitas responden (nama, usia, jenis kelamin, dan waktu lama kerja), (2) Angket kuesioner Kelelahan subjektif dengan kuesioner IFRC Industrial Fatigue Research Commitee of Japanese Association of Industrial Health (1967) yang telah diadaptasi menggunakan bahasa Indonesia. Dalam kuesioner ini dapat dilihat tingkat kelelahan seseorang (3) Sound level meter pengukuran ruangan tempat yang akan diukur dibagi menjadi 3 titik kemudian masing-masing titik dilakukan pengukuran sebanyak 2 kali dan hasil dicatat kemudian diperhitungkan dengan rumus hitung (4) Alat Tulis (5) Temperatur, humidity, wbt and dew point alat ini digunakan untuk mengukur temperatur ruangan.

Cara pengukuran dan pengumpulan data: (1) wawancara dengan menggunakan kuesioner yang telah disediakan. (2) kebisingan di lingkungan kerja diukur dengan sound level meter dengan nilai ambang batas yang ditentukan oleh NIOSH pengukuran kebisingan dilakukan di tiga titik ruangan responden pada masing-masing titik dilakukan 2 kali pengukuran (3) pengukuran temperatur udara dilakukan menggunakan temperatur, humidity, wbt and dew point di ruangan yang telah ditentukan kemudian ruangan dibagi menjadi 3 titik kemudian masing-masing titik dilakukan pengukuran sebanyak 2 kali dan hasil dicatat kemudian dihitung reratanya.

Data diolah dan disajikan dalam bentuk tabel distribusi frekuensi, tabulasi silang dan narasi. Analisis yang digunakan menggunakan uji chi square dengan $\alpha=0,05$, kemudian dilihat nilai koefisien korelasi. 
HASIL

\section{Distribusi Faktor Umur PT. X Jakarta}

Berdasarkan penelitian didapatkan hasil sebagai berikut:

Tabel 1. Distribusi Umur PT. X Jakarta Juli 2015

\begin{tabular}{lcc}
\hline \multicolumn{1}{c}{ Variable } & Jumlah & Persentase \\
\hline Umur Responden (tahun) & & \\
\hline$\leq 30$ tahun & 21 & $46,70 \%$ \\
$31-40$ tahun & 13 & $28,90 \%$ \\
$\geq 41$ tahun & 11 & $24,40 \%$ \\
\hline Total & 45 & $100,00 \%$ \\
\hline
\end{tabular}

Sumber: Data Primer

Berdasarkan hasil penelitian dari 45 orang responden dapat diketahui bahwa umur mayoritas responden berumur $\leq 30$ tahun yaitu sebanyak 21 orang, sebanyak 13 responden berusia 31-40 tahun dan responden yang paling sedikit berusia lbih dari 41 tahu yaitu sebanyak 11 responden.

\section{Distribusi Kebisingan di PT. X Jakarta}

Berdasarkan pengukuran yang dilakukan di kantor baru dan workshop 9 didapatkan hasil sebagai berikut:

Tabel 2. Hasil Pengukuan Intensitas Kebisingan PT. X Jakarta Juli 2015

\begin{tabular}{lcc}
\hline & $\begin{array}{c}\text { Kantor Baru } \\
(\text { dBA })\end{array}$ & $\begin{array}{c}\text { Workshop 9 } \\
\text { (dBA) }\end{array}$ \\
\hline Titik 1 & 79 & \\
P1 & 80 & 90 \\
P2 & & 95 \\
\hline Titik 2 & 80 & 96 \\
P1 & 81 & 97 \\
P2 & & \\
\hline Titik 3 & 80 & 94 \\
P1 & 82 & 96 \\
P2
\end{tabular}

Sumber: Data Primer

Pada kantor baru kebisingan yang paling rendah yaitu $79 \mathrm{dBA}$ sedangkan yang paling tinggi yaitu $82 \mathrm{dBA}$. Rata-rata kebisingan di kantor baru adalah 85 dBA. Pada workshop 9 dapat diketahui bahwa kebisingan yang paling rendah adalah 90 dBA sedangkan yang paling tinggi adalah $97 \mathrm{dBA}$, sedangkan rata-rata kebisingan pada workshop 9 adalah 90 dBA. Rata-rata kebisingan dihitung dengan menggunakan rusum hitung, hal ini karena kebisingan yang terjadi adalah bising implus yaitu kebisingan yang terjadi dengan intensitas sangat tinggi tetapi waktu nya tidak menentu. Hal ini disebabkan karena pemotongan besi tidak dilakukan dengan waktu yang sama, karena pekerja harus memindahkan sendiri besi atau bahan yang akan dipotong.

\section{Distribusi Temperatur Udara di PT. X Jakarta}

Berdasarkan pengukuran yang dilakukan di kantor baru dan workshop 9 didapatkan hasil pada tabel 3.

Hasil pengukuran di kantor baru dapat diketahui bahwa dari ketiga titik temperatur terendah adalah $24^{\circ} \mathrm{C}$ sedangkan yang tertinggi adalah $26^{\circ} \mathrm{C}$, sehingga rata-rata temperatur ruangan pada kantor baru adalah $25^{\circ} \mathrm{C}$. Suhu ruangan di kantor cenderung lebih stabil dan lebih baik dari tempat lain karena diatur dengan menggunakan AC.

Tabel 3. Hasil Pengukuran Temperatur PT. X Jakarta Juli 2015

\begin{tabular}{lcc}
\hline & $\begin{array}{c}\text { Kantor Baru } \\
\left({ }^{\circ} \mathbf{C}\right)\end{array}$ & $\begin{array}{c}\text { Workshop 9 } \\
\left({ }^{\circ} \mathbf{C}\right)\end{array}$ \\
\hline Titik 1 & & \\
P1 & 24 & 34 \\
P2 & 26 & 36 \\
\hline Titik 2 & & \\
P1 & 24 & 34.50 \\
P2 & 26 & 37 \\
\hline Titik 3 & & \\
P1 & 26 & 34.20 \\
P2 & 24 & 36 \\
\hline
\end{tabular}

Sumber: Data Primer

Hasil pengukuran di workshop 9 dapat dilihat bahwa temperatur ruangan di workshop 9 paling rendah adalah $34,20^{\circ} \mathrm{C}$ sedangkan yang paling tinggi adalah $37^{\circ} \mathrm{C}$ terletak di titik 2 . Hasil perhitungan rata-rata temperatur ruangan di workshop 9 adalah $36,38^{\circ} \mathrm{C}$.

\section{Distribusi Kelelahan Subjektif di PT. X Jakarta}

Hasil pengukuran kelelahan subjektif menujukan bahwa dari 45 orang responden semua responden mengalami kelelahan subjektif. Diketahui bahwa sebanyak 40 orang 34 atau $88,9 \%$ mengalami kelelahan dengan kategori ringan, sementara 5 orang atau $11 \%$ mengalami kelelahan dengan kategori sedang, sedangkan untuk kelelahan dengan kategori 
tidak lelah dan lelah berat tidak dirasakan oleh responden.

Berdasarkan hasil wawancara dengan gejala yang paling banyak dirasakan responden yaitu lelah seluruh badan, dan mengalami gangguan tidak stabil saat berdiri.

\section{Hasil Analisis Hubungan Umur PT. X Jakarta dengan Kelelahan Subjektif}

Hasil analisis uji statistik menggunakan chi square $\mathrm{P}$ value $<0,05$ sehingga umur memiliki hubungan yang signifikan dengan kelelahan subjektif. Hal ini menujukan bahwa umur memiliki pemharuh yang besar terhadap kelelahan subjektif pada pekerja

\section{Hasil Analisis Hubungan Kebisingan dengan Kelelahan Subjektif}

Berdasarkan hasil pengukuran dan perhitungan didapatkan hasil:

Tabel 4. Distribusi Kelelahan Subjektif Berdasarkan Kebisingan PT. X Jakarta Juli 2015

\begin{tabular}{lccr}
\hline \multirow{2}{*}{ Kelelahan Kerja } & \multicolumn{2}{c}{ Kebisingan } & Total \\
\cline { 2 - 3 } & $\begin{array}{c}\text { Tidak } \\
\text { Normal }\end{array}$ & Normal & \\
\hline Kelelahan Ringan & 29 & 11 & 40 \\
Kelelahan Sedang & 5 & - & 5 \\
\hline Total & 34 & 11 & 45 \\
\hline
\end{tabular}

Sumber: Data Primer

Hasil pengukuran kelelahan subjektif sebanyak 34 orang responden terpapar kebisingan yang melebihi NAB. Dapat diketahui bahwa dari 45 orang responden semua mengalami keluhan kelelahan kerja. 5 orang responden mengalami kelelahan dengan kategori ringan, kelima orang responden ini berada pada ruangan yang terpapar kebisingan melebihi NAB. Dari hasil wawancara dapat diketahui bahwa waktu kerja responden lebih dari 8 jam, karena sebagian besar bekerja menjalani kerja lembur. Responden yang mengalami kelelahan ringan berjumlah 40 orang di mana 29 orang diantaranya terpapar kebisingan melebihi NAB. Menurut perhitungan statistik kedua variabel tersebut didapatkan dengan nilai $\mathrm{p}=0,313>\alpha=$ 0,05 maka hubungan ini tidak signifikan atau tidak ada hubungan.

\section{Hasil Analisis Hubungan Temperatur Udara PT. X Jakarta dengan Kelelahan Subjektif}

Berdasarkan pengukuran yang dilakukan di kantor baru dan workshop 9 didapatkan hasil sebagai berikut:

Tabel 5. Distribusi Kelelahan Subjektif Berdasarkan Temperatur Udara PT. X Jakarta Juli 2015

\begin{tabular}{lccr}
\hline \multirow{2}{*}{ Kelelahan Kerja } & \multicolumn{2}{c}{ Temperatur Udara } & \\
\cline { 2 - 3 } & $\begin{array}{c}\text { Tidak } \\
\text { Normal }\end{array}$ & Normal & \\
\hline Kelelahan Ringan & 29 & 11 & 40 \\
Kelelahan Sedang & 5 & - & 5 \\
\hline Total & 34 & 11 & 45 \\
\hline
\end{tabular}

Sumber: Data Primer

Dapat diketahui dari Tabel 5 bahwa dari 45 responden 34 orang diantaranya terpapar temperatur yang tidak normal. Responden yang mengalami kelelahan sedang senyak 5 orang dan semua terpapar temperatur yang tidak normal. 40 responden mengalami kelelahan dengan kategori ringan di mana 29 diantaranya terpapar kebisingan yang tidak normal. Menurut perhitungan statistik kedua variabel tersebut didapatkan dengan nilai $\mathrm{p}=0,313>\alpha=$ 0,05 maka hubungan ini tidak signifikan atau tidak ada hubungan.

\section{PEMBAHASAN}

\section{Umur}

Diketahui Bahwa responden memiliki umur yang bervariasi, paling banyak berusia kurang dari 30 tahun yaitu sebanyak 21 responden $(46,70 \%)$, sedangkan yang paling sedikit yaitu responden yang berusia lebih dari 41 tahun yaitu sebanyak 11 responden. Umur seseorang dapat memengarui kondisi tubuh orang tersebut hal ini berkaitan dengan kondisi fisik orang tersebut, secara fisiologis kondisi fisik dan ketahanan tubuh seseorang cenderung menurun sesuai dengan pertambahan usia. Untuk itu sebaiknya pekerja yang berusia lanjut sebaiknya tidak mendapatkan pekerjaan yang terlalu berat karena kondisi fisik nya sudah mulai menurun.

Sesuai dengan penelitian yang dilakukan Nindya (2013), yaitu umur pekerja menunjukkan bahwa terdapat kecenderungan hubungan umur dengan 
tingkat kelelahan kerja. Terdapat 7,92\% pekerja yang berusia lebih dari 40 tahun dan semua pekerja tersebut mengalami kelelahan kerja.

Menurut Tarwaka et al. (2004), kemampuan fisik yang dimiliki seseorang yang paling optimal pada usia 25-30 tahun, setelah itu kapasitas fisik akan menurun $1 \%$ setiap tahun. Penelitian yang dilakukan oleh Priyono (2010), bahwa pekerja yang berusia lanjut atau $>41$ tahun sebaiknya tidak bekerja di tempat yang panas hal ini dikarenakan kelenjar keringat memiliki respons yang lebih lambat dari pada pekerja yang berusia muda.

\section{Kebisingan}

Kebisingan yang dialami pekerja adalah Bising impuls artinya bising yang mempunyai intensitas tinggi dalam waktu singkat dan terjadi tidak konstan. Hal ini berkaitan kondisi di workshop 9 yaitu bagian pemotongan dengan mesin bending. Mesin tidak memotong bahan secara terus-menerus karena pekerja harus terlebih dahulu mengambil bahan yang akan di potong sesuai dengan pesanan, menyebabkan intensitas kebisingan yang tidak konstan tapi terjadi dengan angka yang sangat tinggi sewaktu-waktu. Pada kantor baru mesin yang sering digunakan adalah peralatan kantor yang menyebabkan intensitas kebisingan cenderung lebih stabil. Maka perhitungan di lakukan di beberapa titik kemudian digunakan rumus hitung untuk mengetahui rata-rata intensitas kebisingan di ruangan tersebut.

Hasil perhitungan kebisingan yang dilakukan di bagian produksi workshop 9 dapat diketahui bahwa tingkat intensitas kebisingan adalah $90 \mathrm{dBA}$ sedangkan pada kantor baru adalah 85.12 dBA Hal ini menujukan bahwa pekerja yang berada di bagian produksi mendapat paparan kebisingan melebihi nilai ambang batas (NAB) standar yang telah di tetapkan sesuai dengan Keputusan Menteri Tenaga Kerja No. 51 tahun 1999 Tentang Nilai Ambang Batas Faktor Fisika di Tempat Kerja yaitu dengan waktu kerja 8 jan NAB yang telah ditetapkan yaitu 83-85 dBA. Hal ini diperparah dengan pekerja yang sering lembur sehingga menerima paparan melebihi 8 jam setiap harinya. Kebisingan yang tinggi di workshop 9 disebabkan oleh suara mesin bending dang cutting yang digunakan saat proses produksi. Intensitas kebisingan yang melebihi 85 dBA diwajibkan mengurangi waktu paparan seperti eliminasi atau rotasi kerja.

Kebisingan yang terjadi secara terus menerus dapat berbahaya bagi pekerja. Dampak yang ditimbulkan bias terjadi secara langsung pada telinga (auditory effect) juga bisa mempengaruhi bukan pada indera pendengaran (non auditory effect).

\section{Temperatur Udara}

Pengukuran temperatur udara dilakukan di dua lokasi yaitu pada workshop 9 dan pada kantor baru. Di kedua tempat tersebut dilakukan pengukuran pada 3 titik berbeda Berdasarkan hasil pengukuran temperatur ruangan kedua tempat ini dapat dilihat pada bagian produksi khususnya workshop 9 suhu rata-rata melebihi dari Standar menurut Keputusan Menteri Kesehatan Republik Indonesia No. 1405/ Menkes/IX/2002 Tentang Standar Suhu Lingkungan Kerja untuk

Perindustrian yaitu $18-28^{\circ} \mathrm{C}$, sedangkan untuk kondisi temperatur udara di kantor baru suhunya masih memenuhi standart yaitu $25^{\circ} \mathrm{C}$ hal ini dikarenakan karena kondisi ruangan di kantor diatur dengan menggunakan AC. Suhu udara yang panas pada workshop 9 disebabkan oleh penataan ruangan yang tertutup dan kurangnya ventilasi menyebabkan suhu di dalam ruangan meningkat.

Menurut Suma'mur (1996), pada suhu udara yang panas dan lembab, makin tinggi kecepatan aliran udara malah akan makin membebani tenaga kerja. Pada tempat kerja dengan suhu udara yang panas maka akan menyebabkan proses pemerasan keringat. Beberapa hal buruk berkaitan dengan kondisi demikian dapat dialami oleh tenaga kerja, salah satunya kelelahan kerja.

Suhu panas terutama berakibat menurunnya prestasi kerja pikir. Suhu panas dapat berakibat bagi pekerja misalnya mengurangi kelincahan, memperpanjang waktu reaksi dan waktu pengambilan keputusan, mengganggu kecermatan kerja otak, mengganggu koordinasi syaraf perasa dan motoris (Suma'mur, 1996).

\section{Kelelahan Subjektif}

Hasil penelitian didapatkan responden mengalami lelah ringan sebanyak 40 orang atau $88,90 \%$, sementara 5 orang atau $11,10 \%$ mengalami lelah sedang.

Kelelahan kerja dapat menyebabkan timbulnya beberapa efek kepada pekerja seperti prestasi kerja menurun, fungsi fisiologis motorik dan semangat kerja menjadi menurun. Kelelahan kerja cenderung meningkatkan terjadinya kecelakaan kerja, sehingga hal ini dapat merugikan tenaga kerja dan perusahaan. Tarwaka (2011), menjelaskan bahwa faktor penyebab terjadinya kelelahan di industri sangat bervariasi. 
Kelelahan yang terjadi di PT X dapat disebabkan berbagai macam faktor.

Kelelahan kerja belum memiliki alat ukur yang jelas sehingga sulit untuk dilakukan analisis, terlebih terhadap pekerja yang memiliki pengetahuan kurang. Kebanyakan pekerja kurang memperhatikan gejala kelelahan kerja sehingga tidak mengetahui bahaya yang akan ditimbulkan jika mengalami kelelahan kerja. Untuk itu sebaiknya perusahaan memberikan arahan kepada pekerja mengenai dampak yang dapat ditimbulkan akibat kelelahan kerja dan cara untuk mengatasinya.

\section{Hubungan Umur dengan Kelelahan Subjektif}

Hasil uji statistik menggunakan didapatkan bahwa umur memiliki hubungan yang signifikan dengan kelelahan subjektif. Responden yang memiliki usia lebih cenderung mengalami kelelahan yang lebih besar dari pada responden yang memiliki usia lebih muda. Hal ini dikarenakan kondisi fisik yang mengalami penurunan sesuai dengan usia.

Menurut Tarwaka (2011), kemampuan fisik optimal seseorang dicapai pada saat usia 20-30 tahun dan mencapai puncaknya pada usia 25 tahun. Bertambahnya usia akan diikuti dengan adanya penurunan kapasitas fisik seperti: tajam penglihatan, pendengaran, kecepatan membedakan sesuatu, membuat keputusan dan kemampuan mengingat jangka pendek karena itu usia pekerja yang dapat memengaruhi kinerja, terutama pekerjaan yang memerlukan kekuatan fisik dan konsentrasi yang tinggi.

Menurut Triyunita (2013), hal ini dikarenakan umur yang meningkat akan diikuti dengan proses degenerasi dari organ sehingga dalam hal ini kemampuan organ akan menurun. Dengan adanya penurunan kemampuan organ, maka hal ini akan menyebabkan tenaga kerja akan semakin mudah mengalami kelelahan.

Hasil penelitian menunjukkan terdapat hubungan antara umur dengan kelelahan kerja hal ini disebabkan karena pada umur dengan kategori lebih umur tua telah mengalami perubahan jaringan tubuh, semakin tua umur seseorang maka akan menyebabkan semakin berkurang kekuatan tubuh sehingga akan lebih cepat mengalami kelelahan kerja. Berdasarkan teori umur menurut Wijaya dalam Tarwaka (2004), bahwa tua merupakan proses menghilangnya secara perlahan-lahan kemampuan jaringan untuk memperbaiki diri, mengganti dan mempertahankan struktur dan fungsi normalnya. Akan tetapi umur dan kelelahan subjektif memiliki hubungan yang lemah hal ini dikarenakan perasaan lelah lebih bersifat umum dan mudah dirasakan oleh siapa saja termasuk usia muda karena ini menyangkut fisik sehat atau tidaknya seseorang, sistem kerja yang diterapkan serta durasi istirahat yang dibutuhkan itu berbeda-beda.

Setiap hari responden bekerja selama 8 jam dengan waktu istirahat 1 jam yang digunakan untuk makan dan beribadah. Selain waktu istirahat yang sudah ditetapkan, ada juga istirahat pendek secara spontan yang sering dilakukan, misalnya saat menunggu bahan baku pekerja mendapatkan waktu untuk penyegaran kembali (recovery).

\section{Hubungan Kebisingan dengan Kelelahan Subjektif}

Kelelahan subjektif kategori kelelahan sedang berada pada ruangan dengan kebisingan yang tidak normal. Menurut perhitungan statistik kedua variabel tersebut didapatkan dengan nilai $p=0,313$ $>\alpha=0,05$ maka hubungan ini tidak signifikan atau tidak ada hubungan. Nilai koefisien kontingensinya sebesar 0,19 sehingga termasuk hubungan sangat rendah. Peneliti menilai bahwa kebisingan bukan merupakan faktor utama terjadinya kelelahan kerja, karena pekerja sudah terbiasa dengan kondisi bising pada lingkungan kerja sehingga pekerja tidak merasa kebisingan sebagai suatu masalah selain itu masih banyak faktor pendukung terjadinya kelelahan kerja lainnya selain itu pekerja sudah penyesuaian tubuh atau adaptasi terhadap bunyi yang keras sehingga telah terbiasa dalam menerima kebisingan. Pekerja yang telah terbiasa dan terlatih dalam melakukan pekerjaan memungkinkan

Hal ini kurang sesuai dengan hasil yang dikemukakan oleh Widana (2014), pengukuran kelelahan pada pekerja menujukan jumlah tenaga kerja yang terpapar dengan tingkat kebisingan di atas NAB berjumlah 13 orang dan 6 orang dengan tingkat kebisingan di bawah NAB. Risiko yang paling besar terjadi akibat kebisingan adalah gangguan pendengaran dan sakit pada telinga karena mendengar suara yang keras dan tidak teratur secara berulang. Hal ini dapat menyebabkan kondisi tubuh merasa lebih cepat lelah. Kebisingan pada saat proses produksi tidak bias dikurangi dengan penggunaan APD agar mengurangi dampak yang dapat ditimbulkan akibat suara yang terlalu bising.

Intensitas kebisingan yang tinggi di tempat kerja dapat menyebabkan stress sehingga mempercepat timbulnya kelelahan. Kelelahan dapat menurunkan kekuatan otot yang disebabkan karena kehabisan 
tenaga dan peningkatan sisa-sisa metabolisme, seperti asam laktat dan karbondioksida. Kelelahan juga dapat menurunkan motivasi, menaikkan ambang rangsang, serta menurunkan kecermatan dan kecepatan pemecahan persoalan. Kebisingan yang tinggi dapat menyebabkan gangguan terhadap tenaga kerja salah satunya yaitu gangguan fisiologis dan gangguan psikologis mengakibatkan kelelahan pada tenaga kerja selain itu juga dapat menyebabkan gangguan komunikasi dan gangguan pendengaran pada alat pendengaran.

Upaya penanggulangan kebisingan berdasarkan teknik pelaksanaannya dapat dilakukan dengan beberapa cara diantaranya yaitu melakukan pengendalian pada sumber bising adalah pemeriksaan secara berkala terhadap peralatan merubah cara kerja, pembatasan jenis dan jarak lalu lintas, mengatur selang waktu kerja dan tenaga kerja diharapkan dapat menggunakan APD seperti ear plug atau ear muff yang telah disediakan oleh pihak perusahaan.

\section{Hubungan Temperatur dengan Kelelahan Subjektif}

Berdasarkan tabel 3 dapat dilihat bahwa sebanyak 5 orang mengalami kelelahan subjektif kategori kelelahan sedang berada pada ruangan dengan temperatur yang tidak normal Pada saat suhu udara sangat panas tubuh menjadi cepat lelah karena di dalam secara alami menghasilkan panas, jika panas lingkungan terus meningkat dapat mempercepat proses metabolisme yang menyebabkan tubuh menjadi lebih cepat lelah. Temperatur akan memberkan beban tambahan bagi tenaga kerja. Suhu yang panas tidak hanya berasal dari suhu matahari tapi juga dapat berasal dari lingkungan sekitar seperti penataan stasiun kerja, peralatan yang ada di tempat kerja, serta panas yang berasal dari mesin.

Temperature yang tinggi cepat membuat konsentrasi berkurang dan menguras tenaga sehingga memacu terjadinya kelelahan kerja yang lebih tinggi dari pada temperature yang lebih rendah. Akan tetapi temperatur dan kelelahan kerja memiliki hubungan yang tidak signifikan Peneliti menilai tidak adanya hubungan ini karena meskipun suhu udara panas masih banyak faktor yang bisa mendukung terjadinya kelelahan seperti beban kerja, waktu istirahat konsumsi makan dan air. Penyebab lain yaitu pekerja sudah terbiasa bekerja di suhu panas sehingga tidak merasakan perbedaan bekerja di suhu yang normal atau tidak normal, menyebabkan tubuh menjadi lebih cepat lelah

\section{SIMPULAN}

Umur responden paling banyak yaitu lebih dari 30 Tahun sebanyak 13 orang. Berdasarkan hasil pengukuran kebisingan didapatkan bahwa 34 pekerja terpapar kebisingan yang melebihi NAB.

Hasil Pengukuran di kantor Baru didapatkan nilai kebisingan 79-82 dB sedangkan pada workshop 9 didapatkan nilai $90-96 \mathrm{~dB}$.

Hasil pengukuran di kantor baru dapat diketahui temperatur terendah adalah $24^{\circ} \mathrm{C}$ sedangkan yang tertinggi adalah $26^{\circ} \mathrm{C}$, sehingga rata-rata temperatur ruangan pada kantor baru adalah $25^{\circ} \mathrm{C}$. Sedangkan di workshop 9 dapat dilihat bahwa temperatur ruangan di workshop 9 paling adalah $36,38^{\circ} \mathrm{C}$.

Hasil pengukuran menujukan kondisi kebisingan dan temperatur udara di workshop 9 melebihi NAB yang telah ditetapkan oleh peraturan.

Responden yang merasakan kelelahan subjektif dengan kategori ringan sebanyak 40 responden, dan dengan kategori sedang sebanyak 5 responden. Terdapat hubungan yang signifikan antara umur dan kelelahan subjektif sedangkan, temperature dan kebisingan tidak memiliki hubungan signifikan dengan kelelahan subjektif.

Saran untuk perusahahan Kelelahan kerja dapat ditanggulangi dengan cara, pemberian gizi kerja yang memadai sesuai dengan jenis pekerjaan dan beban kerja, waktu kerja yang diselingi istirahat pendek dan istirahat untuk makan, beban kerja yang

Tabel 6. Rekapitulasi Analisis Bivariat Hubungan Umur Kebisingan, dan Temperatur dengan kelelahan Subjektif Individu di PT. X Jakarta Juli 2015

\begin{tabular}{ccccc}
\hline No & Variabel Terikat & Variabel Bebas & Sig (p-value) & Kesimpulan \\
\hline 1 & Kelelahan subjektif & Umur & 0,612 & Ada Hubungan \\
2 & Kelelahan subjektif & Kebisingan & 0,313 & Tidak Ada Hubungan \\
3 & Kelelahan subjektif & Temperatur & 0,313 & Tidak Ada Hubungan \\
\hline
\end{tabular}


tidak berlangsung lama serta pembebasan lingkungan kerja dari kebisingan, getaran dan iklim kerja yang panas. Dilakukan pengaturan pada tempat kerja yang baik seperti penambahan ventilasi dan kipas angin. Menyediakan tempat istirahat sehingga pekerja dapat tidur atau mandi pada saat jam istirahat. Selain itu juga dapat dilakukan rotasi kerja yang teratur dan Alat Pelindung Diri (APD) seperti earplug. Perusahaan memberikan kebijakan berkaitan dengan usia sehingga pekerja yang berusia lebih dari 40 tahun dapat mendapatkan pekerjaan yang sesuai dengan kemampuannya. Dilakukan pengaturan pada tempat kerja yang baik seperti penambahan ventilasi dan kipas angin. Untuk pekerja dapat memperbanyak konsumsi air putih untuk menjaga suhu tubuh agar tetap stabil. Pengaturan penggunaan waktu istirahat yang tepat. Perusahaan juga sebaiknya tetap menggunakan sistem manajemen Keselamatan dan Kesehatan Kerja (K3) dengan mengadakan pelatihan K3, inspeksi K3, pemantauan lingkungan, dan melakukan penggantian alat pelindung secara terjadwal agar dapat mereduksi kebisingan yang ada di tempat kerja

\section{DAFTAR PUSTAKA}

Adelina, A., dan Alfi. Pengaruh Intensitas Kebisingan Lingkungan Kerja terhadap Waktu Reaksi Karyawan PT. PLN (Persero) Sektor Barito PLTD Trisakti Banjarmasin. Jurnal. Universitas Lambung Mangkurat.http://download.portalgaruda.org/ article.php? article $=96016 \&$ val $=5073$. $($ sitasi 21 Januari 2016)

Andriani, W.K. 2015. Hubungan Kebisingan dan Kelelahan Subjektif dengan Kelelahan Subjektif. Skripsi. Surabaya: Universitas Airlangga.

Irma, S,. dan Andi. 2014. Faktor yang Berhubungan dengan Kelelahan Kerja pada Unit Produksi Paving Block CV. Sumber Galian Kecamatan Biringkanaya Kota Makassar. Jurnal Fakultas Kesehatan Masyarakat UNHAS. http://repository. unhas.ac.id/bitstream/handle/123456789/10783/ IRMA.\%20MR\%20K11110315.pdf? sequence=1. (sitasi 21 Januari 2016)

Keputusan Menteri Kesehatan Republik Indonesia Nomor 1405/Menkes/SK/XI/2002 Tentang
Persyaratan Kesehatan Lingkungan Kerja Perkantoran dan Industri. Jakarta: Menteri Kesehatan Republik Indonesia.

Keputusan Menteri Tenaga Kerja Nomor: Kep-51/ Men/1999 Tentang Nilai Ambang Batas Faktor Fisika di Tempat Kerja. Jakarta: Menteri Tenaga Kerja.

Nindya, E., Daru. 2013. Hubungan Beban Kerja Fisik, Kebisingan dan Faktor Individu dengan Kelelahan Pekerja Bagian Weaving PT. X Batang 2011. Jurnal Kesehatan Masyarakat UNDIP, Volume 2. http://download.portalgaruda.org/ article.php?article $=73859 \& \mathrm{val}=4700$. (sitasi 20 Januari 2016)

Priyono, D. 2010. Iklim Kerja dan Kelelahan Subjektif pada Pekerja Proyek Relokasi Jalan Arteri Raya Porong - Siring 1 Paket 3 Sidoarjo. Skripsi. Surabaya: Universitas Airlangga.

Setyawati, L. 2010. Selintas tentang Kelelahan Kerja. Yogyakarta: Amara Books.

Suhartana, S., Yuniawati. 2013. Hubungan Beban Kerja Fisik, Kebisingan dan Faktor Individu dengan Kelelahan Pekerja bagian Weaving PT. X Batang 2011. Jurnal. Kesehatan Masyarakat UNDIP, Volume 2. http://download.portalgaruda. org $/$ article.php? article $=73859 \&$ val $=4700$. (sitasi 20 Januari 2016)

Suma'mur, P.K. 1996. Hygiene Perusahaan dan Keselamatan Kerja, Cetakan Kedua. Jakarta: CV. Haji Mas Agung.

Tarwaka, B.S., Sudiajeng. 2004. Ergonomi untuk Keselamatan, Kesehatan Kerja dan Produktivitas. UNIBA PRESS. Cetakan Pertama. Surakarta.

Tarwaka. 2011. Ergonomi Industri. Dasar-dasar Pengetahuan Ergonomi dan Aplikasi di Tempat Kerja. Surakarta: Harapan Press.

Undang-Undang Republik Indonesia Nomor 13 Tahun 2003 Tentang Ketenagakerjaan, Jakarta: DPR RI.

Widana., Pujiandi. 2014. Kebisingan Berpengaruh terhadap Beban Kerja dan Tingkat Kelelahan Tenaga Kerja di Industri Pengolahan Kayu. Jurnal. https://jurnal.ftumj.ac.id/index.php/ semnastek/article/view/336 (Sitasi 20 januari 2016) 